\title{
Day-neutral Strawberries for High Tunnel Production in the Central United States
}

\author{
Kelly Gude ${ }^{1,5}$, Cary L. Rivard ${ }^{2,6}$, Sara E. Gragg ${ }^{3,7}$, \\ Kimberly Oxley ${ }^{2,8}$, Petros Xanthopoulos ${ }^{4,7}$, and \\ Eleni D. Pliakoni ${ }^{1,7,9}$
}

\begin{abstract}
ADDITIONAL INDEX WORDs. spring-planted, hoophouses, evaporative cooling,
\end{abstract} plasticulture, season extension

SUMMARY. Specialty crop production in high tunnel systems has greatly expanded in the central United States. Strawberry (Fragaria $\times$ ananassa) may be a viable highvalue crop for high tunnel growers, but fall-planted production systems have a high opportunity cost in regard to winter production space. This study investigates the feasibility of spring-planted day-neutral strawberry cultivars in a high tunnel production system in Kansas. Furthermore, the goals of this report are to identify day-neutral cultivars that are successful in this production system and investigate the utility of evaporative cooling (EC), as they relate to fruit yield and marketability as well as incidence of gray mold (caused by Botrytis cinerea). High tunnel trials were conducted at the Kansas State University Olathe Horticulture Research and Extension Center during 2014 and 2015. Six commercially available cultivars were evaluated: Albion, Evie 2, Monterey, Portola, San Andreas, and Seascape in both years. Mature fruit $(90 \%$ to $100 \%$ red) were harvested twice weekly for total and marketable (fruit with no defects) fruit yield. The results indicate that 'Portola' had the highest total fruit weight in both years at 0.60 and $0.51 \mathrm{~kg} / \mathrm{plant}$, respectively, and was significantly higher than 'Monterey', 'Albion', and 'San Andreas' in both years $(P<0.05)$. In 2014, 'Portola', 'San Andreas', and 'Albion' produced the largest total fruit average weight (grams /fruit) and were significantly larger than 'Seascape' and 'Evie 2' $(P<0.05)$. In 2015, 'Portola' had significantly larger fruit than all the other cultivars except San Andreas $(P<0.05)$. Marketability percent by weight ranged from $76.5 \%$ to $88.6 \%$ across both years and the highest marketability was observed with 'Albion' (89\% and $83 \%$ ) and 'Monterey' (85\% and $84 \%$ ) in 2014 and 2015 , respectively. An examination of fruit production during the early, mid-, and late seasons was used to determine seasonal dynamics of each cultivar and the high tunnel system. The overall trend was that total fruit weight was highest during the midseason and total average fruit weight was largest in the early season. However, 'San Andreas' and 'Seascape' had similar levels of production between the early and midseason and had the lowest level of production in the midseason, particularly in the 2015 trial. In our trials, the use of EC did not affect fruit weight or gray mold incidence on strawberry fruit. Based on the crop productivity observed in our study, this production system has the potential to extend the season for strawberry growers in the central United States or provide a high-value rotational crop for existing high tunnel growers that does not require winter production space.

$\mathrm{H}$ igh tunnels are unheated, polyethylene film-covered greenhouse structures used around the world to reduce limitations imposed by harsh weather and temperature fluctuation (Lamont, 2009; Wells and Loy, 1993). High tunnels provide season extension for farmers who grow high-value crops, such as strawberry (Demchak, 2009). Strawberry plants are the most widely grown berry crop in high tunnel systems (Lamont, 2009). This system reduces leaf wetness from excess moisture, gray mold, and pest damage and provides environmental protection to improve percent marketability
(Carey et al., 2009; Salame-Donoso et al., 2010).

A study comparing open-field vs. high tunnel systems for strawberry production in Wichita, KS, found that high tunnel production resulted in larger fruit, larger leaf area, greater leaves and shoot biomass, and fewer runners (Kadir et al., 2006). In Kansas, it was found that June-bearing plants in a high tunnel produced 5 weeks before open-field production with an average of $5^{\circ} \mathrm{C}$ warmer crowns in comparison with open-field plants (Kadir et al., 2006). High tunnels can substantially improve marketable yields, shelf life, and extend the harvest season for strawberry fruit (Belasco et al., 2013; Kadir and Carey, 2004; Salame-Donoso et al., 2010). However, high tunnels require careful management to prevent excessive temperatures and humidity inside the structure during the warmest months (Jensen and Malter, 1995).

In open-field systems, there are several studies that highlight the importance of environment for growing strawberry successfully. Several studies have found that production temperatures, genotype, and irrigation are the most important parameters that regulate crown development and, consequently, fruit size (Connor et al., 2002; Hortynski et al., 1991; Wang and Camp, 2000). Temperature also affects the rate of nutrient uptake and metabolism, strawberry color development, and firmness. At higher temperatures, transpiration increases, which can increase nutrient uptake because of high light and optimal growing temperature (Kader, 2002; Paull, 1999). It has been reported that growing temperature is a major factor that can affect fruit size, which tends to decrease with temperatures above $29^{\circ} \mathrm{C}$ (Kumakura and Shishido, 1994; Wang and Camp, 2000). Ideal crown development occurs at temperatures $\approx 13$ to $29{ }^{\circ} \mathrm{C}$, which encourages high yields with large fruit size. Temperatures above $29^{\circ} \mathrm{C}$ encourage excessive crown development, which will potentially reduce subsequent fruit size, fruit weight, and overall plant growth (Hellman and Travis, 1988; Kumakura and Shishido,

\begin{tabular}{llll}
\hline $\begin{array}{l}\text { Units } \\
\text { To convert U.S. to SI, } \\
\text { multiply by }\end{array}$ & U.S. unit & SI unit & $\begin{array}{l}\text { To convert SI to U.S., } \\
\text { multiply by }\end{array}$ \\
\hline 0.3048 & $\mathrm{ft}$ & $\mathrm{m}$ & 3.2808 \\
3.7854 & $\mathrm{gal}$ & $\mathrm{L}$ & 0.2642 \\
2.54 & inch(es) & $\mathrm{cm}$ & 0.3937 \\
0.4536 & $\mathrm{lb}$ & $\mathrm{kg}$ & 2.2046 \\
1.1209 & $\mathrm{lb} / \mathrm{acre}$ & $\mathrm{kg} \cdot \mathrm{ha}^{-1}$ & 0.8922 \\
28.3495 & $\mathrm{Oz}$ & $\mathrm{g}$ & 0.0353 \\
$\left({ }^{\circ} \mathrm{F}-32\right) \div 1.8$ & ${ }^{\circ} \mathrm{F}$ & ${ }^{\circ} \mathrm{C}$ & $\left({ }^{\circ} \mathrm{C} \times 1.8\right)+32$
\end{tabular}


1994; Masaru et al., 2016). Junebearing strawberry cultivars that were grown within a high tunnel had a greater fruit yield (weight, average size, and number) in comparison with the open-field production system (Kadir et al., 2006), and the authors suggested that this benefit is the result of a more conducive environment within the high tunnel in the central United States.

Kansas often receives daily temperatures above $29^{\circ} \mathrm{C}$ from late June to early August (Kansas Mesonet, 2014). One solution to this challenge is using high tunnels with shadecloth and proper ventilation (Rowley et al., 2011). Another option is to use EC to reduce the internal plant temperature. In strawberry production, EC consists of an overhead sprinkler system installed between rows within the high tunnel. The plant cools as the water that was applied from the overhead sprinklers absorbs the heat energy and is converted into gas through evaporation (Thompson et al., 1993). The use of EC has been suggested as a potential method to decrease strawberry plant internal temperature and increase yields or postharvest quality of fruit (Koike et al., 2009; Lantz et al., 2010; Roos and Jones, 2016). Evaporative cooling or the technique of supplemental irrigation by microjet or sprinkler in addition to drip tape during plant propagation or at planting has shown to delay flowering and increase crown size, average fruit weight, and plant vigor of bare-root

\footnotetext{
The assistance of Helena Chiebao Pontes is gratefully acknowledged, and we thank the Olathe Horticulture Research and Extension Center. We also acknowledge the National Strawberry Sustainable Initiative who provided partial funding for this project and Nourse Farms for providing plant materials.

${ }^{1}$ Department of Horticulture and Natural Resources, Kansas State University, 22201 W. Innovation Drive, Olathe, KS 66061

${ }^{2}$ Olathe Horticulture Research and Extension Center, 35230 W. 135th Street, Olathe, KS 66061

${ }^{3}$ Department of Animal Sciences and Industry, Kansas State University, 22201 W, Innovation Drive, Olathe, KS 66061

${ }^{4}$ Decision \& Information Sciences Department, School of Business Administration, Stetson University, 421 N. Woodland Boulevard, DeLand, FL 32723

${ }^{5}$ Graduate Research Assistant

${ }^{6}$ Associate Professor

${ }^{7}$ Assistant Professor

${ }^{8}$ Research Associate
}

${ }^{9}$ Corresponding author. E-mail: epliakoni@ksu.edu.

https://doi.org/10.21273/HORTTECH03937-17 plants in Florida (Hochmuth et al., 2006a, 2006b).When this method was used by Dara et al. (2016) during plant establishment in commercial open-field production in California, it increased plant health by a reducing two-spotted spider mite (Tetranychus urticae) infestation and gray mold; however, no indication of yield or internal temperature changes was found. Evaporative cooling has also been used for orchards (Yang and Bryla, 2016) and commercial berry production systems (Evans, 2004; Parchomchuk and Meheriuk, 1996). In California, EC was effective in vineyards (Vitis vinifera) at increasing yield and delaying fruit maturity (Aljibury et al., 1975). It has also been used in apple (Malus domestica) production to enhance color and quality during storage (Evans, 2004; Parchomchuk and Meheriuk, 1996).

In the central United States, fallplanted June-bearing cultivars are typically used for open-field and high tunnel strawberry production because of their high-yielding harvest period that can last up to 6 weeks (Demchak et al., 2010; Kadir et al., 2006). However, many growers may wish to grow other crops in the fall and winter in high tunnels to maximize revenue. Furthermore, yields of dayneutral cultivars are typically higher than those of June-bearing cultivars because of the extended harvest season (Lantz et al., 2010; Rowley et al., $2011)$. In the high-elevation region of Utah with summer temperatures above $29^{\circ} \mathrm{C}$, it was found that peak high tunnel production of June-bearing cultivars starts 4 weeks before peak high tunnel day-neutral cultivar production (Rowley et al., 2011). In the high tunnel production system in Utah, day-neutral strawberry fruit are typically harvested from late May to mid-December, with total yields greater than June-bearing cultivars (Rowley et al., 2011).

Growing spring-planted dayneutral strawberry cultivars in a high tunnel system could be a new way for strawberry growers in the central United States to protect their crop while ensuring a longer harvest season than traditional open-field production. Furthermore, they could provide a viable rotation alternative for tomato (Solanum lycopersicum), which is the number one crop grown in high tunnels (Knewtson et al., 2010). Day-neutral fruit production begins in the late spring and lasts until midfall. Lantz et al. (2010) estimated the feasibility of high tunnel strawberry production in the northeastern U.S. market through an economic study, although the initial cost of the high tunnel was not included. They concluded that growing strawberry in the high tunnel was profitable during the 15 - to 20 -week harvest period if the day-neutral fruit yielded 0.75 to $1.25 \mathrm{lb} /$ plant and sold for $\$ 2.00$ to $\$ 4.00$ per pound or yielded $0.60 \mathrm{lb} /$ plant and sold for $\$ 3.00$ to $\$ 4.00$ per pound (Lantz et al., 2010). Premium prices for strawberry fruit occur in October and November, when production is low on a national scale (Belasco et al., 2013; Pollack and Perez, 2008) and may be driven further by consumer demand. Because day-neutral cultivars are planted in the spring, this system would allow growers to integrate fall and winter crops into the high tunnel system (Heidenreich et al., 2012; Rowley et al., 2011). By contrast, June-bearing cultivars have a higher opportunity cost when grown in high tunnels as they are typically planted in fall and eliminate valuable winter production space (Salame-Donoso et al., 2010).

Spring-planted day-neutral strawberry production in high tunnels in Kansas could be a profitable solution for specialty crop growers. However, extreme summer temperatures events in the central United States may negatively affect fruit yield and quality. Therefore, the objectives of this research were to 1 ) investigate the feasibility of spring-planted day-neutral cultivars in a high tunnel production system in the central United States as they relate to fruit yield and marketability as well as gray mold incidence, 2 ) identify day-neutral cultivars that are successful in this system, and 3 ) investigate the impact of EC on fruit yield and marketability.

\section{Materials and methods}

Trials were conducted at the Kansas State University Olathe Horticulture Research and Extension Center (OHREC) during 2014 and 2015, and the experimental design was identical across years. OHREC is located in Johnson County, KS (lat. $38.884347^{\circ} \mathrm{N}$, long. $\left.94.993426^{\circ} \mathrm{W}\right)$. The soil is a Chase silt loam ( $\mathrm{pH}$ 6.5). The trial was located within a threeseason high tunnel $[200 \mathrm{ft}$ long $\times 24$ 
ft wide (Haygrove, Mount Joy, PA)]. In 2015 , the trial was planted in a different but identical tunnel to facilitate crop rotation. Shadecloth $(30 \%)$ was applied when daily high temperatures consistently reached $29^{\circ} \mathrm{C}$ (15 May 2014 and 2015) and removed at the end of the production season. In both years, bare-root strawberry plants were provided by a commercial nursery for the trials (Nourse Farms, Whately, MA).

EXPERIMENTAL DESIGN. The experiment was arranged in a split-plot, randomized complete block design with four replications. The main plots included the use of EC (with and without) and the subplots consisted of the six cultivars that were randomly assigned to the subplots. Six commercial cultivars of day-neutral strawberry were evaluated including Evie 2 from Edward Vinson Breeders (Kent, England), in addition to Albion, Monterey, Portola, San Andreas, and Seascape from the University of California, Davis. In both production seasons, the trial included the entire width of the high tunnel, which consisted of four beds that were $154 \mathrm{ft}$ long. Each bed included two rows that were planted in staggered arrangement. There were 12 subplots per bed (48 plots total). At least 20 buffer plants $(10.5 \mathrm{ft})$ were included at the ends of each bed. These plants were excluded from the trial and their purpose was to prevent any unwanted bias from microclimate effects related to the endwalls.

The sprinkler range for the EC system covered the width of two rows and was installed (with and without sprinklers) directly between beds 1 and 2 as well as beds 3 and 4 . Therefore, each experimental replication consisted of two adjacent beds that were $77 \mathrm{ft}$ long $\times 12 \mathrm{ft}$ wide. Within each replication, the main plot included the EC treatments (with and without). Each subplot consisted of 20 plants grown in a staggered doublerow with 12 -inch in-row spacing and 12 inches between the rows. Each subplot was $10 \mathrm{ft}$ long and the spacing between the beds was $5 \mathrm{ft}$ from centerto-center. In between each of the main plots was $6 \mathrm{ft}$ of space from end-to-end to reduce interplot interference that could result from the EC system.

Growing METHODs. Bare-root strawberry plants (Nourse Farms, South Deerfield, MA) were used for the trials in both years. Because of late winter weather in Kansas in 2014, the bare-root plants were initially planted in 2.5-inch pots with potting mix (Fafard 3B; Conrad Fafard, Agawam, $\mathrm{MA}$ ) and grown in a greenhouse for 3 weeks before being planted in the three-season high tunnel. In 2015, late winter conditions in Massachusetts resulted in a 2 -week delay in shipping bare-root plants and they were planted directly into the high tunnel. Plants were grown on raised beds with black polyethylene mulch and drip irrigation (4-inch emitter spacing) was used (Turbo Tape; Jain Irrigation, Fresno, CA). Weeds were suppressed between rows via woven fabric mulch and runners were removed on a weekly basis. In 2014, a granular fertilizer mix was incorporated into beds preplant at a rate of $30 \mathrm{lb} /$ acre of nitrogen $(\mathrm{N})$ from a combination of calcium nitrate [15.5N-0P-0K (YARA6031CN; Yara North America, Burton, $\mathrm{OH})]$ and potassium nitrate $[13.5 \mathrm{~N}-0 \mathrm{P}-46.2 \mathrm{~K}$ (Multi-K; Haifa Chemicals, Haifa Bay, Israel)]. In 2015, the same preplant fertilizer amount was applied with additional calcium phosphate $[0 \mathrm{~N}-$ 45P-0K (Hi-Yield 32275; VPG, Bonham, TX)] and magnesium [0N0P-0K-12.9S-9.8Mg (Epsom Salt F-1253; Vi-Jon, St. Louis, MO)] based on soil tests. The trials were planted on 7 Apr. 2014 and 23 Apr. 2015. Strawberry plants were fertigated with 10 applications of calcium nitrate and potassium nitrate that were rotated in 2014 from 18 Apr. to 7 Aug. at $10 \mathrm{lb} /$ acre N. Similarly in 2015 , plants received nine applications from 17 Apr. to 17 Aug., at the same rate.

Evaporative cooling. The EC system used consisted of a 1000-gal plastic tank filled with potable water and positioned at one end of the high tunnel. It was equipped with a timer to automatically dispense water daily once activated. The EC was supplied through white polyvinyl chloride piping ( $\mathrm{SCH} 40 \mathrm{BE}$; Charlotte Pipe and Foundry Co., Charlotte, NC) by overhead sprinkler heads (VibroSpray HF; Netafim, Fresno, CA) that were situated at the specific plots as described in the experimental design. EC was applied once when air temperature consistently reached $85{ }^{\circ} \mathrm{F}$ by 12:00 PM for $5 \mathrm{~min}$, which was chosen to saturate the plants to the drip point. In 2014, EC was applied from 24 June to 14 Aug. $(30 \mathrm{~d}$ throughout the production period). In 2015 , application began on 13 July and lasted until 8 Sept. (38 d throughout the production period).

Data Collection. Strawberry fruit were harvested weekly or biweekly from each plot at the commercially ripened stage (90\% to $100 \%$ red). They were graded as marketable or nonmarketable and the fruit number and weight were recorded. Nonmarketable fruit were determined based on the presence of decay, gray mold, small size (smaller than 1 inch diameter), and pest damage or other defects. At the end of each growing season, the plants were stripped of all fruit larger than 1 inch (including green or white) and weighed to determine overall plant productivity. In 2014 , strawberry fruit were harvested from 10 May to 6 Oct. In 2015, strawberry fruit were harvested from 31 May to 6 Oct.

If strawberry fruit had any presence of gray mold, they were harvested and the individual fruit (fruit per plant) were counted separately to determine the preharvest decay. In 2014 , incidence of gray mold was measured eight times on 30 July; 14, 18, 20, and 25 Aug.; and 2, 5, and 18 Sept. In 2015, incidence of gray mold was measured 24 times on 22 and 25 June; 6, 9, 13, 16, 20, 24, 27 , and 30 July; 4, 7, 10, 13, 17, 21, 24, 27, and 31 Aug.; 8, 14, 21, and 29 Sept.; and 6 Oct.

SEASONAL DYNAMICS OF FRUIT PRODUCTION. During both growing years, we identified three distinct production seasons (early, mid, and late) based on the timing of peak fruit harvests across the 6-month production period. Examining the yield dynamics between those seasons helps identifying trends across cultivars and within the high tunnel system. These dates were determined by examining the flushes of fruit harvest throughout the production year. In 2014 , the early harvest season was 7 weeks ( 10 May to 31 June), midseason was 7 weeks (1 July to 14 Aug.), and late season was 7 weeks (15 Aug. to 6 Oct.). In 2015, the early harvest season was 4 weeks (31 May to 31 June), midseason was 7 weeks ( 1 July to 14 Aug.), and late season was 7 weeks (15 Aug. to 6 Oct.). Distinct peaks in production occurred between 
these dates in both years. In 2015, early season production was only 4 weeks because of the later planting date. The defined early season coincided with peak production of June-bearing cultivars in controlled environments in Kansas (Kadir et al., 2006). Midseason occurred during the period with the greatest concentration of days with temperatures more than $85^{\circ} \mathrm{F}$. Late-season production occurred during the transition into fall growing conditions.

Statistical analysis. Total and marketable per plant fruit weight (kilograms per plant) were determined using the fruit weight and plant count data from each plot. Total and marketable average fruit weight (grams per fruit) were determined using the fruit weight and fruit number data from each plot. Marketability (percent by weight) was calculated as a percent of the total yield based on fruit weight. The resulting data from the entire production season are shown in Tables $1,2,4$, and 5, and Figs. 2-3. The effects of EC on yield and marketability were determined based on harvest data that were collected after the system was turned on (24 June 2014 and 13 July 2015) until the end of the growing season and the resulting data are shown in Table 3 and Fig. 1.

To evaluate the significant effects $(\alpha=0.05)$ of cultivars, EC, seasons (early, mid, and late), and production years, analysis of variance (ANOVA) tests were performed to determine which factors and interactions between factors affected the total and marketable fruit yield, as well as the marketability percent by weight of the strawberry fruit harvested. When interactions were not significant, the means of the factors were combined. Significant differences between mean cultivar responses, season, and year were evaluated using Tukey's honestly significant difference procedure for multiple comparisons $(\alpha=0.05)$. Data in Tables 1, 3, 4, and 5, and Figs. 1-3 were analyzed using JMP (version 13; SAS Institute, Cary, NC). Data in Table 2 were analyzed using SAS (version 9.3; SAS Institute).

\section{Results}

We observed significant cultivar $\times$ year and cultivar $\times \mathrm{EC} \times$ year interaction terms for several parameters, including fruit weight, average fruit weight, and marketability (data not shown). Therefore, data from 2014 and 2015 were analyzed similarly, but independently. Similarly, there were no significant effects of cultivar $\times$ year, $\mathrm{EC} \times$ year, or cultivar $\times \mathrm{EC} \times$ year for total and marketable fruit weight. Table 1 includes the resulting probability values for ANOVA tests that were used to determine the significance of cultivar and EC in each year as well as statistical interaction between factors. For all parameters measured, there were no significant interactions between EC and cultivar within either year; the combined data (with or without EC) are shown in Table 2 as the main effects of cultivar for all the yield data collected.
The production year and the cultivars significantly affected the total fruit weight (Tables 1-2). In 2014, total fruit weight was higher than in $2015(P<0.0001)$ with a mean of $0.45 \mathrm{~kg} /$ plant, compared with 0.34 $\mathrm{kg} /$ plant (Table 2). In 2014, 'Portola', 'Evie 2', and 'Seascape' yielded the highest total fruit weight of the six cultivars evaluated. 'Portola' had significantly greater total fruit weight than 'Monterey', 'Albion', and 'San Andreas' $[P<0.05$ (Table 2) $]$. Similar to the total fruit weight, the 2014 'Portola' marketable fruit weight was $25 \%$ higher than the season mean. In 2015, 'Portola' had significantly higher total fruit yield than all cultivars except Evie 2 and produced 32\% greater total fruit weight than the season mean $[P<0.05$ (Table 2)]. In 2015, strawberry fruit from 'Portola' had greater marketable fruit weight than all the other studied cultivars $(P<0.05)$ and produced $34 \%$ greater marketable fruit weight than the season mean (Table 2).

Cultivar significantly affected the total average fruit weight $[P<0.0001$ (Table 1)] and in both production years, Portola and San Andreas had the highest total average fruit weight (Table 2). In 2014, 'Portola', 'San Andreas', and 'Albion' were similar to each other. 'Seascape' had a smaller total average fruit weight in 2014 than all the other cultivars tested except Evie $2[P<0.05$ (Table 2$)]$. In 2015, 'Portola' strawberry fruit had larger total average fruit weight in comparison with all cultivars other

Table 1. Probability values for total and marketable fruit yield (weight and average size) and percent marketability for the six strawberry cultivars grown in a high tunnel with and without evaporative cooling (EC) during the production period from May to October at Olathe, KS, in 2014 and 2015.

\begin{tabular}{|c|c|c|c|c|c|}
\hline \multirow[b]{2}{*}{ Treatment $^{\mathrm{z}}$} & \multicolumn{2}{|c|}{ Total fruit yield ${ }^{y}$} & \multicolumn{2}{|c|}{ Marketable fruit yield } & \multirow{2}{*}{$\begin{array}{c}\text { Marketable } \\
\text { (\% by wt) }\end{array}$} \\
\hline & Wt (kg/plant) & Avg wt (g/fruit) & Wt (kg/plant) & Avg wt (g/fruit) & \\
\hline \multicolumn{6}{|l|}{2014} \\
\hline Cultivar & $<0.0001$ & $<0.0001$ & 0.0002 & $<0.0001$ & 0.0009 \\
\hline $\mathrm{EC} \times$ cultivar & NS & NS & NS & NS & NS \\
\hline \multicolumn{6}{|l|}{2015} \\
\hline $\mathrm{EC} \times$ cultivar & NS & NS & NS & NS & NS \\
\hline
\end{tabular}

${ }^{\mathrm{z}}$ The experimental design was a split-plot randomized complete block design with four replications; main plots included the use of evaporative cooling treatment (with and without EC) and the subplots consisted of cultivars. Each plot consisted of 20 plants grown in a staggered double row; $90 \%$ to $100 \%$ mature fruit were harvested once or twice weekly from May to October and all cumulative fruit harvest data were included in the statistical analysis. We observed significant cultivar $\times$ year and cultivar $\times$ EC $\times$ year interaction for average total and marketable fruit size and marketability; therefore, data from 2014 and 2015 were analyzed similarly, but independently; $1 \mathrm{~kg}=2.2046 \mathrm{lb}, 1 \mathrm{~g}=$ $0.0353 \mathrm{oz}$.

${ }^{\mathrm{y}}$ Analysis of variance to determine which factors and interactions between factors affected the main total and marketable yield effects (weight and average weight), and marketable (percent by weight) data from the entire production season were used for this analysis.

${ }^{\mathrm{x}}$ Nonsignificant at $\alpha=0.05$. 
Table 2. Main effects of cultivar on total and marketable fruit yield and marketable percentage of day-neutral strawberry cultivars grown in a high tunnel at Olathe, KS, in 2014 and 2015.

\begin{tabular}{|c|c|c|c|c|c|}
\hline \multirow[b]{2}{*}{ Cultivar $^{\mathrm{z}}$} & \multicolumn{2}{|c|}{ Total fruit yield ${ }^{y}$} & \multicolumn{2}{|c|}{ Marketable fruit yield } & \multirow{2}{*}{$\begin{array}{c}\text { Marketable } \\
\text { (\% by wt) }\end{array}$} \\
\hline & Wt (kg/plant) & Avg wt (g/fruit) & Wt (kg/plant) & Avg wt (g/fruit) & \\
\hline \multicolumn{6}{|l|}{2014} \\
\hline Evie 2 & $0.53 \mathrm{ab}$ & $8.79 \mathrm{~cd}$ & $0.42 \mathrm{ab}$ & $9.36 \mathrm{~cd}$ & $79.4 \mathrm{~b}$ \\
\hline Seascape & $0.48 \mathrm{ab}$ & $8.22 \mathrm{~d}$ & $0.40 \mathrm{abc}$ & $8.50 \mathrm{~d}$ & $84.2 \mathrm{ab}$ \\
\hline Monterey & $0.40 \mathrm{bc}$ & $9.64 \mathrm{bc}$ & $0.34 \mathrm{bc}$ & $9.92 \mathrm{bc}$ & $84.8 \mathrm{ab}$ \\
\hline Year mean & $0.45 * * *$ & 9.92 & $0.38 * * *$ & 10.49 & 83.8 \\
\hline \multicolumn{6}{|l|}{2015} \\
\hline Portola & $0.51 \mathrm{a}$ & $8.71 \mathrm{a}$ & $0.42 \mathrm{a}$ & $9.23 \mathrm{a}$ & $82.0 \mathrm{ab}$ \\
\hline Evie 2 & $0.37 \mathrm{ab}$ & $7.26 \mathrm{bc}$ & $0.28 \mathrm{~b}$ & $8.13 \mathrm{ab}$ & $76.5 \mathrm{~b}$ \\
\hline Seascape & $0.33 \mathrm{~b}$ & $6.30 \mathrm{c}$ & $0.26 \mathrm{~b}$ & $6.63 \mathrm{c}$ & $79.2 \mathrm{ab}$ \\
\hline
\end{tabular}

${ }^{\mathrm{z}}$ The experimental design was a split-plot randomized complete block design with four replications; main plots included the use of evaporative cooling treatment [with and without evaporative cooling (EC)] and the subplots consisted of cultivars. Each plot consisted of 20 plants grown in a staggered double-row; $90 \%$ to $100 \%$ mature fruit were harvested once or twice weekly from May to October and all cumulative fruit harvest data were included in the statistical analysis.

${ }^{\mathrm{y}}$ Data from plots with and without EC are included to show the main effects of cultivar within each year. No significant cultivar $\times$ EC interactions were observed within the years; $1 \mathrm{~kg}=2.2046 \mathrm{lb}, \mathrm{lg}=0.0353 \mathrm{oz}$.

'Values representing the means separated within a column within a year marked with the same letter do not differ using Tukey's honestly significant difference procedure at $\alpha=0.05$.

${ }^{*},{ }^{* *},{ }^{* *}$ indicate the 2014 season mean of each main effect that is significantly different in comparison with 2015 at $P<0.01,0.001$, or 0.0001 , respectively, for total and marketable weight that interactions did not occur between the year and the cultivar.

Table 3. Main effects of the use of evaporative cooling (EC) on total and marketable fruit yield and marketable percentage of day-neutral strawberries grown in a high tunnel at Olathe, KS, in 2014 and 2015.

\begin{tabular}{|c|c|c|c|c|c|}
\hline \multirow[b]{2}{*}{ Treatment $^{\mathrm{z}}$} & \multicolumn{2}{|c|}{ Total fruit yield ${ }^{y}$} & \multicolumn{2}{|c|}{ Marketable fruit yield } & \multirow{2}{*}{$\begin{array}{c}\text { Marketable } \\
\text { (\% by wt) }\end{array}$} \\
\hline & Wt (kg/plant) & Avg wt (g/fruit) & Wt (kg/plant) & Avg wt (g/fruit) & \\
\hline \multicolumn{6}{|l|}{2014} \\
\hline Without EC & 0.33 & 8.70 & 0.29 & 9.25 & 88.80 \\
\hline$P$ value & $\mathrm{NS}^{\mathrm{x}}$ & 0.0002 & NS & 0.0008 & 0.0004 \\
\hline \multicolumn{6}{|l|}{2015} \\
\hline$P$ value & NS & NS & NS & NS & NS \\
\hline
\end{tabular}

${ }^{\mathrm{z}}$ The experimental design was a split-plot randomized complete block design with four replications; main plots included the use of evaporative cooling treatment (with and without EC) and the subplots consisted of cultivars. Each plot consisted of 20 plants grown in a staggered double-row; $90 \%$ to $100 \%$ mature fruit were harvested once or twice weekly from May to October. Cultivars are combined for every main effect within each year because no interactions were observed between the cultivar and the evaporative cooling treatments.

${ }^{\mathrm{y}}$ Only cumulative fruit harvest data for the period when $\mathrm{EC}$ was being applied was included in the statistical analysis; $1 \mathrm{~kg}=2.2046 \mathrm{lb}, 1 \mathrm{~g}=0.0353 \mathrm{oz}$.

${ }^{\mathrm{x}}$ Nonsignificant at $\alpha=0.05$.

than San Andreas $[P<0.05$ (Table 2)]. Trends among the marketable average fruit weight were similar to total average fruit weight in both production years. 'Portola' had the highest marketable average fruit weight than the other cultivars and strawberry fruit from Seascape had the lowest marketable average fruit weight than the other cultivars tested (Table 2).

The marketability percent was affected by cultivar $[P<0.05$ (Table 1 ) $]$ and it ranged from $76.5 \%$ to $88.6 \%$
(Table 2). During 2014, 'Albion' had the highest marketability percent and was statistically significant when compared with 'Evie 2' and 'San Andreas' $(P<0.05)$. In 2015, 'Monterey' had the highest proportion of marketable fruit and it was significantly higher than 'Evie 2' $(P<0.05)$. In both years, 'Albion' and 'Monterey' had the two highest values for marketability percent and 'Evie 2' and 'San Andreas' had the two lowest values for marketability percentage (Table 2). 'Portola' had intermediate levels of marketability percentage and was similar to the cultivars with the highest and lowest values in both years (Table 2 ).

Conversely to Tables 1 and 2 , Table 3 includes probability values from ANOVA tests that were conducted using yield data during the period when EC was being applied as described in the materials and methods. Similarly to the full data set, significant interactions occurred for several parameters when the years 
Table 4. Probability values for total fruit weight, total average size, and marketable percentage of day-neutral strawberries grown during early, mid-, and late season in a high tunnel at Olathe, KS, in 2014 and 2015.

\begin{tabular}{|c|c|c|c|}
\hline \multirow[b]{2}{*}{ Interactions $^{\mathrm{z}}$} & \multicolumn{3}{|c|}{ Main effect ${ }^{y}$} \\
\hline & $\begin{array}{c}\text { Total fruit wt } \\
(\mathrm{kg} / \text { plant })\end{array}$ & $\begin{array}{c}\text { Total fruit avg wt } \\
\text { (g/fruit) }\end{array}$ & $\begin{array}{c}\text { Marketable } \\
\text { (\% by wt) }\end{array}$ \\
\hline Year & $<0.0001$ & $<0.0001$ & $<0.0001$ \\
\hline Season $^{\mathrm{x}}$ & $<0.0001$ & $<0.0001$ & $<0.0001$ \\
\hline Cultivar & $<0.0001$ & $<0.0001$ & 0.0003 \\
\hline Year $\times$ season & $<0.0001$ & $<0.0001$ & 0.0032 \\
\hline Season $\times$ cultivar & $<0.0001$ & 0.0049 & $\mathrm{NS}^{\mathrm{w}}$ \\
\hline Year $\times$ cultivar & NS & NS & NS \\
\hline Year $\times$ season $\times$ cultivar & NS & NS & NS \\
\hline
\end{tabular}

${ }^{\mathrm{z}}$ The experimental design was a split-plot randomized complete block design with four replications; main plots included the use of evaporative cooling treatment (with and without evaporative cooling) and the subplots consisted of cultivars. Each plot consisted of 20 plants grown in a staggered double-row; $90 \%$ to $100 \%$ mature fruit were harvested once or twice weekly from May to October and all cumulative fruit harvest data were included in the statistical analysis.

${ }^{\mathrm{y}}$ Analysis of variance to determine which factors and interactions between factors affected the main total yield effects (weight and average size) and percent marketability by weight; $1 \mathrm{~kg}=2.2046 \mathrm{lb}, \mathrm{l} \mathrm{g}=0.0353 \mathrm{oz}$.

${ }^{x}$ Three distinct production seasons (early, mid, and late) based on the timing of peak fruit harvests across the sixmonth production period; early season (10 May to 31 June 2014, 31 May to 31 June 2015), midseason (1 July to 13 Aug. 2014, 1 July to 13 Aug. 2015), and late season (15 Aug. to 6 Oct. 2014, 15 Aug. to 6 Oct. 2015).

wonsignificant at $\alpha=0.05$.

Table 5. Main effects of the season factors (early, mid, and late) on the marketable percentage of strawberries growing in a high tunnel at Olathe, $\mathrm{KS}$, in 2014 and 2015.

\begin{tabular}{llc}
\hline Yr $^{\mathbf{z}}$ & Season $^{\mathbf{y}}$ & $\begin{array}{c}\text { Marketable } \\
(\% \text { by wt })\end{array}$ \\
\hline 2014 & Early & $76.5 \mathrm{~b}^{\mathrm{x}}$ \\
& Mid & $86.0 \mathrm{a}$ \\
& Late & $86.5 \mathrm{a}$ \\
& Year mean & 83.0 \\
& Early & $75.2 \mathrm{~b}$ \\
& Mid & $83.9 \mathrm{a}$ \\
& Late & $78.1 \mathrm{~b}$ \\
& Year mean & 79.0 \\
\hline
\end{tabular}

${ }^{\mathrm{z}}$ The experimental design was a split-plot randomized complete block design with four replications; main plots included the use of evaporative cooling treatment (with and without evaporative cooling) and the subplots consisted of cultivars. Each plot consisted of 20 plants grown in a staggered double-row; $90 \%$ to $100 \%$ mature fruit were harvested once or twice weekly from May to October and all cumulative fruit harvest data were included in the statistical analysis. Treatments and cultivars are combined for every main effect within each growing season because no interactions were observed.

${ }^{\mathrm{y}}$ Early season (10 May to 31 June 2014, 31 May to 31 June 2015), midseason (1 July to 13 Aug. 2014, 1 July to 13 Aug. 2015), and late season (15 Aug. to 6 Oct. 2014, 15 Aug. to 6 Oct. 2015).

${ }^{\mathrm{x}}$ Values representing the means separated within a column marked with the same letter do not differ using Tukey's honestly significant difference procedure at $\alpha=0.05$.

were combined and there were no significant effects for $\mathrm{EC} \times$ cultivar when the years were analyzed independently. Therefore, the main effects of EC are shown in Table 3. There were no significant effects of EC on total or marketable fruit weight in either production year (Table 3 ). EC significantly affected total and marketable average weight during the 2014 trial $[P<0.001$ (Table 3$)]$. Both total and marketable average fruit weight were greater when EC was used in 2014 , but no significant effects were observed in the 2015 trial (Table 3 ). Similarly, the implementation of EC affected the marketability percent during $2014(P<0.001)$, but there was no significant effect in 2015 (Table 3 ). In 2014, strawberry fruit growing under the EC had lower marketability than the strawberry fruit that were grown without EC $[P<0.001$ (Table 3$)]$.

The number of fruit with visible gray mold was counted throughout the 2014 and 2015 harvest seasons. Similarly to Table 3 , incidence of fruit with visible gray mold during the period when the EC was being used is presented in Fig. 1. Across production years, the incidence of gray mold on strawberry fruit ranged from $2.6 \%$ to $13.3 \%$. Our results show that with or without EC, Evie 2 had a higher incidence of fruit with gray mold compared with the other cultivars during both years, although the results from 2015 were not statistically significant; $13.2 \%$ and $7.9 \%$ of the fruit harvested from Evie 2 had gray mold in 2014 and 2015, respectively. There were no significant main effects of EC as it relates to gray mold incidence.

SEASONAL DYNAMICS OF FRUIT PRODUCTION. As described in the materials and methods section, the yield data from the entire harvest period were divided into three time periods (season) when strawberry fruit were harvested. Therefore, seasonal dynamics of cultivars could be presented for the early-, mid-, and late-season production. Statistically significant interactions occurred for both year $\times$ season and season $\times$ cultivar $[P<0.01$ (Table 4$)]$. Therefore, the simple effects for season $\times$ cultivar $x$ year are presented. Figures 2 and 3 allow statistical inferences to be made both horizontally (across cultivars and years) and vertically (across seasons) for each individual cultivar and year.

No significant differences in total fruit weight were observed between the cultivars during the early season in both years. The total fruit weight was highest in the midseason and all the cultivars investigated performed similarly during the early and late season (Fig. 2). However, all cultivars other than San Andreas produced significantly higher total fruit weight during the midseason in $2014(P<0.05)$. In 2015 , only 'Portola' produced significantly higher fruit yield in the midseason than the early season $[P<0.05$ (Fig. 2)]. During the midseason, 'Portola' was the highest yielding cultivar by total fruit weight with significantly greater yields in comparison with all cultivars other than Evie 2 and Seascape. Similarly, Portola produced significantly higher total fruit weight than all cultivars other than Evie 2 during the 2015 midseason period. Interestingly, in 2014 , the late-season harvest period had significantly lower fruit weight for all cultivars compared with the midseason $(P<0.05)$, whereas in 2015 , they were all similar, with the exception of Seascape (Fig. 2). During the late season, 'Portola' yielded significantly higher fruit weight than 'Evie 2', 'San Andreas', and 'Seascape' in 2015.

Total average fruit weight (grams/ fruit) during the three portions of the growing season (early, mid, and late) are displayed in Fig. 3. The season that the strawberry fruit were harvested significantly affected the total average fruit weight, but significant interaction between season and cultivar indicates that not all cultivars performed similarly $[P<0.01$ (Table 4$)]$. No significant differences were observed between the cultivars during the early season except that San 


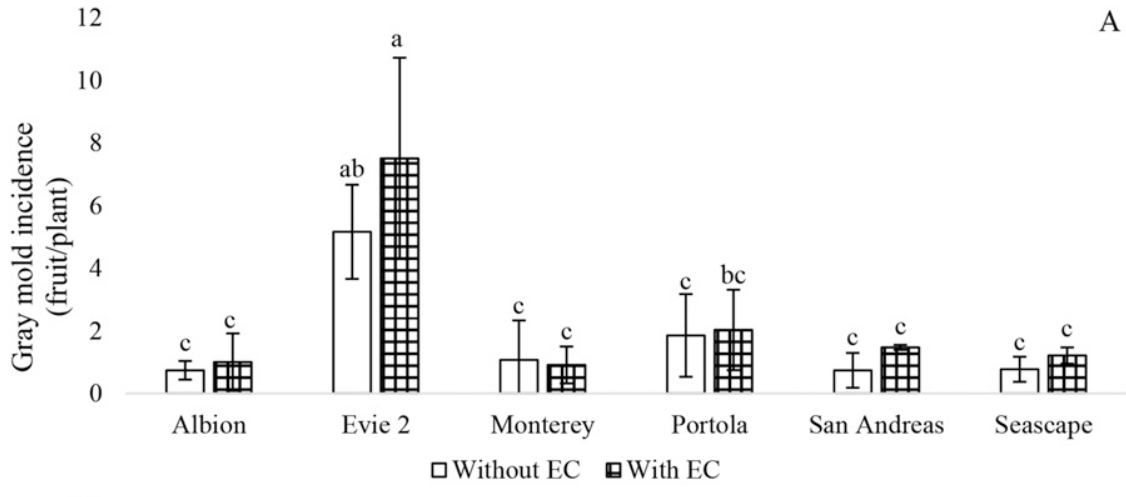

12

B

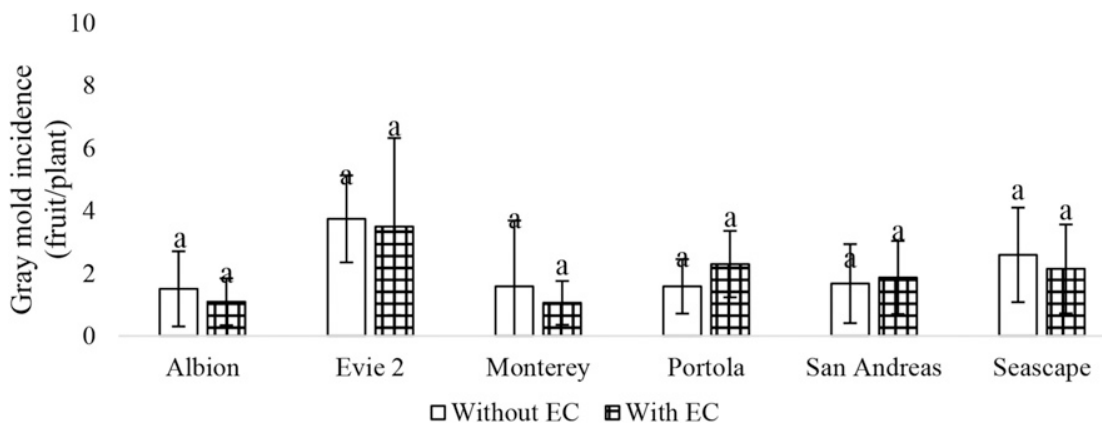

Fig. 1. Gray mold incidence on strawberry plants grown within a high tunnel during (A) 2014 and (B) 2015 trials at Olathe, KS. Means marked with the same letter do not differ among six day-neutral strawberry cultivars and evaporative cooling (EC) treatments (with and without EC) using Tukey's honestly significant difference procedure at $\alpha=0.05$.

Andreas fruit were significantly larger than Seascape in $2014[P<0.05$ (Fig. $3)]$. Across all the cultivars, the total average fruit weight was highest in the early season and tended to decrease from early to midseason. However, 'Portola' maintained similar total and marketable average fruit weight in the midseason as compared with the early season in both years and 'Albion' followed a similar trend in 2014. During the midseason, 'Portola' had larger fruit than 'Evie 2' and 'Seascape' in 2014 and 'Seascape' alone in 2015. In 2014, several cultivars performed similarly in the late season to the midseason in regard to average total fruit weight including Portola, Evie 2, San Andreas, and Seascape. The other cultivars tested in 2014 and all cultivars in 2015 had smaller total average fruit weight in the late season than the midseason. The late-season berries were statistically smaller than the early-season berries for all cultivars throughout both the production years $[P<0.05$ (Fig. 3$)]$.

The marketability percentage was significantly affected by cultivar and season, and there was no significant effect of season $x$ cultivar, year $\times$ cultivar, or year $\times$ season $\times$ cultivar. Therefore, the main effects of season for both years are shown in Table 5 . In both years, the early season had the lowest marketability percentage and was significantly lower than the midseason $[P<0.05$ (Table 5)]. In 2014, the percentage of marketable fruit was highest during the late season and was statistically higher than the early season $(P<0.05)$, whereas in 2015 , the marketability percent in the late season was intermediate (Table 5 ).

\section{Discussion}

The goals of this report were to investigate the feasibility of producing day-neutral spring-planted strawberry in high tunnels in the central United States, identify successful cultivars, and investigate the utility of $\mathrm{EC}$ in this system. Overall, similar trends were seen across both growing season in regard to cultivar selection. However, fruit production varied between the years and mean total fruit production was $0.45 \mathrm{~kg} /$ plant in 2014 and 0.34 $\mathrm{kg} /$ plant in 2015 . Both of those means were within the desired range of total fruit weight reported for day-neutral cultivars within a high tunnel (Lantz et al., 2010). In 2014, every cultivar other than San Andreas fell within or exceeded the desired range of total yield fruit weight reported for dayneutral cultivars within a high tunnel, which was 0.34 to $0.56 \mathrm{~kg} /$ plant (Lantz et al., 2010). However, in 2015, only 'Portola' and 'Evie 2' fell within this desired range.

It is important to note that there were significant main effects for year when comparing the trials in 2014 and 2015 for marketable and total fruit weight. Although, we do not have sufficient data to understand why yields were lower in 2015 , it is likely that the planting method may have contributed to this trend. In 2014 , bare-root plants were grown as transplants for 3 weeks in soilless media before planting in the high tunnel, whereas in 2015, bare-root plants were planted directly into the soil, which occurred 2 weeks later than the 2014 planting date, as described in the growing methods. It has been reported in open-field production systems that strawberry transplants (i.e., plugs) are more likely to perform better in regard to root establishment, plant growth, and subsequent fruit production compared with bare-root plants (Durner et al., 2002; Hochmuth et al., 2006a, 2006b; Poling, 2006; Pritts and Handley, 1998). In addition, it has been reported that strawberry plants produced higher yields from an earlier planting date in day-neutral production in Utah, and delayed planting resulted in lower than optimum yields for 'Albion' and 'Evie 2' (Rowley et al., 2011). Earlier planting encourages strawberry plants to develop and maintain high yields throughout the entire production season (Lantz et al., 2010). In our trials, a three-season high tunnel was used, which cannot be covered with poly film until after the last threat of heavy snow. Growers who use fourseason high tunnels would potentially be able to plant earlier more consistently. It is not clear how or if the process of growing a strawberry transplant in the greenhouse before planting in the high tunnel would be advantageous, and research in this area would be useful even for growers who are using four-season high tunnels. Conversely, in 2015, bare-root plants were delivered later than planned because of 

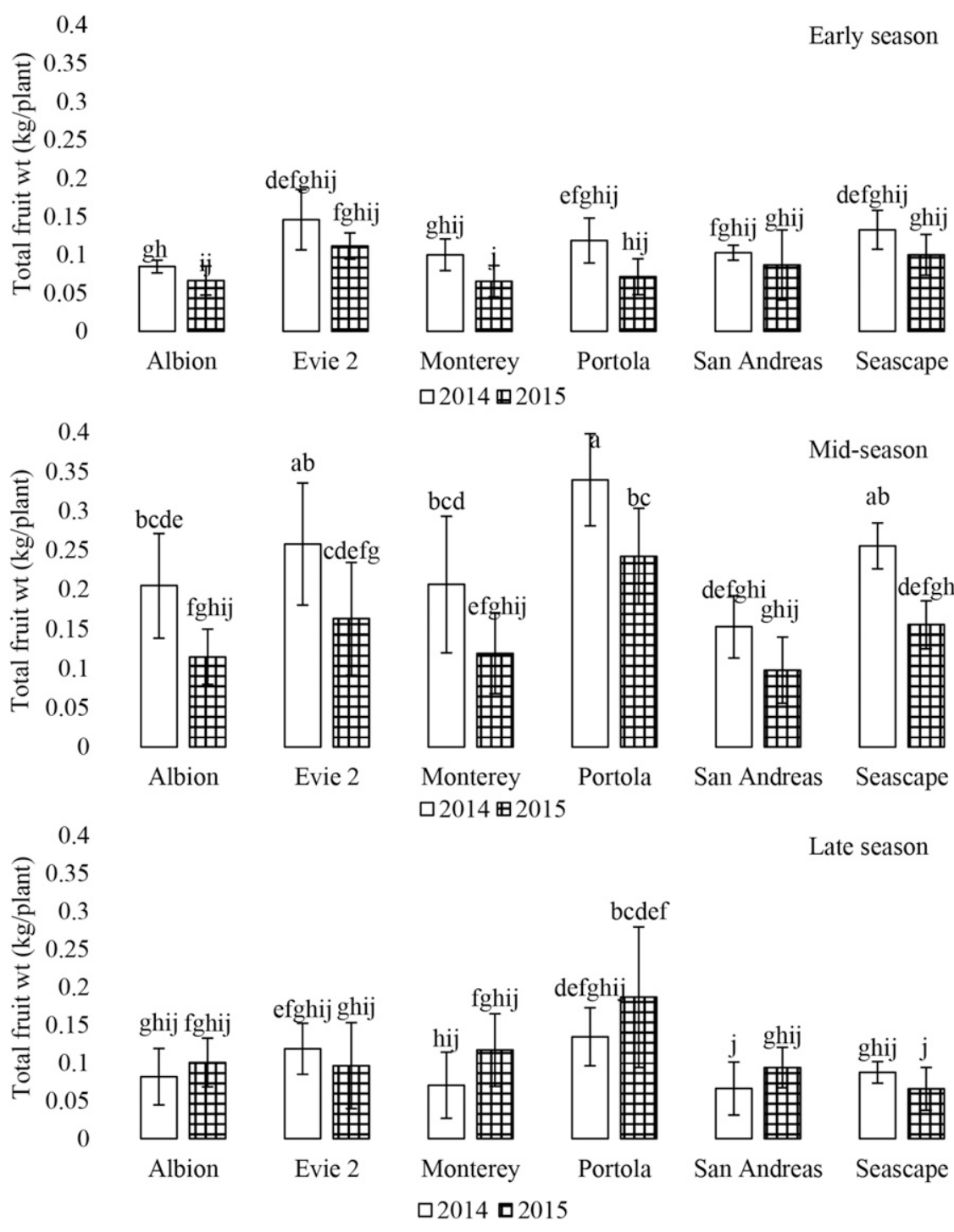

Fig. 2. Total fruit weight of six day-neutral strawberry cultivars grown in a high tunnel at Olathe, KS, during the early season (10 May to 31 June 2014, 31 May to 31 June 2015), midseason (1 July to 13 Aug. 2014, 1 July to 13 Aug. 2015), and late season (15 Aug. to 6 Oct. 2014, 15 Aug. to 6 Oct. 2015). Means marked with the same letter do not differ using Tukey's honestly significant difference procedure $(P \leq 0.05)$ and statistically, inferences can be made vertically (across seasons) and horizontally (across cultivars and years); $1 \mathrm{~kg}=2.2046 \mathrm{lb}$.

late winter conditions at the nursery. This may be a barrier for growers who wish to use this system but are purchasing plant materials from nurseries in northern growing region(s) of the United States.

In the high altitude climate of South Korea, Ruan et al. (2013) observed the yield and fruit quality among June-bearing and the following day-neutral cultivars in high tunnels: Albion, Monterey, Portola, and San Andreas. The marketable fruit weight reported for day-neutral cultivars growing in high tunnels was $0.32 \mathrm{~kg} /$ plant (Ruan et al., 2013).
In our study, the average day-neutral plant produced marketable yields of $0.38 \mathrm{~kg} /$ plant in 2014 and $0.28 \mathrm{~kg} /$ plant in 2015. The fruit was as numerous in 2014 and 2015 but with a smaller average fruit weight in 2015 . Day-neutral plants typically have an average fruit weight of 8 to $20 \mathrm{~g}$ / fruit (Lantz et al., 2010; Rowley et al., 2011). In 2014, all cultivars fell within this range, whereas in 2015 , only Portola and San Andreas fell within the range. In our study, larger fruit were generally observed during the early season. This is typical and the first set of strawberry flowers in an annual production system (Poling, 2005 ) are known as "King Blossoms" as they provide the largest, most marketable fruit. Every cultivar in both growing years was within the expected total average fruit weight for day-neutral cultivars of 8 to $20 \mathrm{~g}$ /fruit during early and midseason. However, many of the cultivars had relatively low average fruit weight, particularly during the late harvest season, which may be problematic for growers. Further research is needed to maintain desirable average fruit weight in the late season.

We saw the total average fruit weight peak during the midseason for both production years from 1 July to 14 Aug. Rowley et al. (2011), reported similar findings for high tunnel production in Utah with peak fruit weight and average weight in early and midseason vs. late-season or mid-August and beyond. The cause of the decreased fruit weight during the late season may be attributed to hot August temperatures, which reduces successful pollination in many commodities (Ledesma and Sugiyama, 2005). Similarly, a controlled study in Japan observed high temperatures on protein expression in strawberry and found that heat shock proteins were induced at $33{ }^{\circ} \mathrm{C}$ daytime temperatures to result in photosynthetic thermotolerance and pollen interference; however, the fruit yield from the study varied by cultivar and more research is required to understand the observations (Ledesma et al., 2004). In our trials, the highest consistent summer temperatures were observed at the end of July and throughout August in 2014 and 2015, which followed the fruit developed during the midseason. Strawberry has a 30 to 40 -d cycle from anthesis to harvest (Symons et al., 2012). Therefore, the effects of high summer temperatures during the midseason probably resulted in lower fruit yield during the late season. This trend has been reported in other studies (Rowley et al., 2011) and was evident in our data.

The trend of the individual cultivars was very similar across the two growing years and suggests that Portola, Evie 2, or both would be the best day-neutral cultivars for use in high tunnel systems in the central United States. 'Portola' had the highest total and marketable fruit weight in both years. Furthermore, the marketable fruit weight of 'Portola' was significantly 


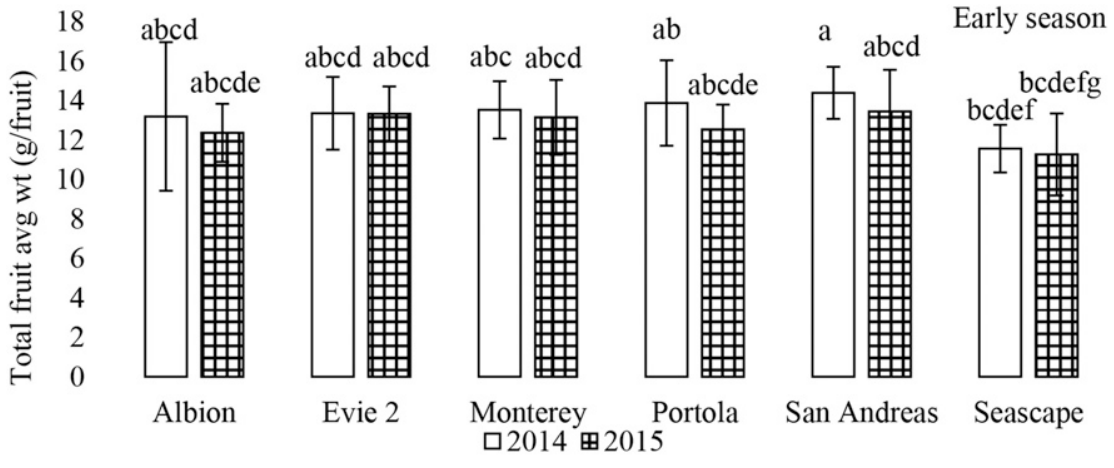

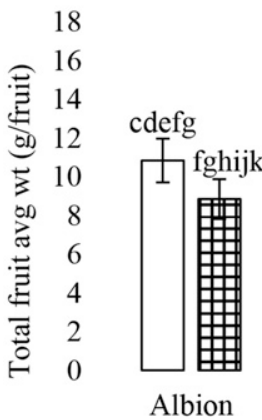

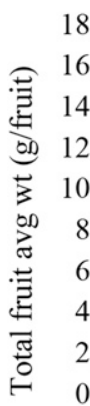

8

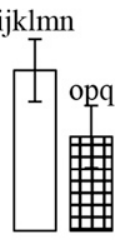

Albion

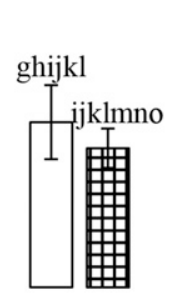

Evie 2

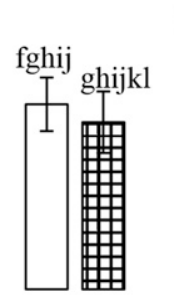

Monterey $\square 2014$ 由2015

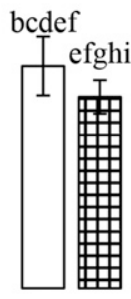

Portola
Mid-season

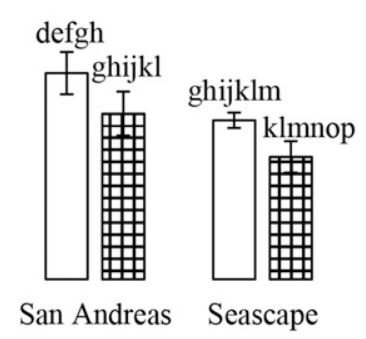

Late season

Fig. 3. Total fruit average weight of six day-neutral strawberry cultivars grown in a high tunnel at Olathe, KS, during the early season (10 May to 31 June 2014, 31 May to 31 June 2015), midseason (1 July to 13 Aug. 2014, 1 July to 13 Aug. 2015), and late season (15 Aug. to 6 Oct. 2014, 15 Aug. to 6 Oct. 2015). Means marked with the same letter do not differ using Tukey's honestly significant difference procedure $(P \leq 0.05)$ and statistically, inferences can be made vertically (across seasons) and horizontally (across cultivars and years); $1 \mathrm{~g}=\mathbf{0 . 0 3 5 3} \mathrm{oz}$.

higher than all other cultivars tested in 2015. It is also important to note that only 'Portola' and 'Evie 2' fell within the desired range of total fruit weight described by Lantz et al. (2010) in both years, although 'Portola' had $37.8 \%$ higher yield than 'Evie 2' in 2015.

'Portola' was released from at the University of California, Davis, and little information has been reported as it relates to high tunnel production in the United States (Lantz et al., 2010). Similar to our findings, Ruan et al. (2013), found 'Portola' to produce the highest marketable yield in comparison with the other day-neutral cultivars at $0.53 \mathrm{~kg} /$ plant in a high tunnel study in South Korea. In addition, they observed that 'Portola' had two spikes in production during the late-season period (August and late September). Researchers at the University of Minnesota found that 'Portola' produced $1.63 \mathrm{lb} /$ plant in low tunnels (Petran, 2016). Furthermore, 'Portola' is reported to produce a large, light-colored fruit (HoashiErhardt and Walters, 2014; Lantz et al., 2010). Similar results were seen in our study in which Portola was one of the two cultivars that produced the largest berries in both seasons compared with the other cultivars tested.
'Evie 2' was found to be very suitable for high tunnels in regard to fruit weight in the northeast while also noting a small average fruit weight (Lantz et al., 2010), as was observed in this study. In contrast, Rowley et al. (2011) found large average fruit weight and possible heat tolerance as well when grown in highelevation high tunnels in Utah. 'Evie 2' plants produced an average of 1.17 $\mathrm{lb} /$ plant when grown within a low tunnel in Minnesota (Petran, 2016). Although 'Evie 2' had high total fruit production in this study, the total and marketable average fruit weight was small in comparison with the other cultivars tested.

'Seascape' is a popular day-neutral cultivar that is reported to have resistance to gray mold and good yields (Demchak, 2009; Rowley et al., 2011). Rowley et al. (2011) found 'Seascape' produced $0.28 \mathrm{~kg} /$ plant in high tunnels in Utah. Meanwhile, Petran (2016), found that 'Seascape' produced $1.26 \mathrm{lb} /$ plant within low tunnels at two locations in Minnesota. In our study, 'Seascape' produced $0.48 \mathrm{~kg} /$ plant in 2014 , but $0.33 \mathrm{~kg} /$ plant in 2015. Although 'Seascape' plants are reported to produce a moderate average fruit weight at 10 to $15 \mathrm{~g} /$ fruit (Hoashi-Erhardt and Walters, 2014), in our study, the average fruit weight was smaller than those previously reported.

Similar to the findings in this study, Ruan et al. (2013) reported that 'San Andreas' produced low marketable fruit weight $(0.31 \mathrm{~kg} /$ plant $)$. Conversely, 'San Andreas' produced a marketable mean weight of $0.99 \mathrm{lb} /$ plant in low tunnels in Minnesota (Petran, 2016), which is $\approx 50 \%$ higher fruit yield than we saw in this study. The low total fruit weight observed in our trials may be due to lower earlyseason yields of 'San Andreas'. Similar to 'Portola', 'San Andreas' had a consistently large average fruit weight and fell within the desired range for day-neutral cultivars at greater than $8 \mathrm{~g} /$ fruit in both production years in this study.

'Albion' is grown mostly in California and has an elongated fruit shape with heavy foliage and resistance to verticillium wilt [ Verticillium dabliae (Lantz et al., 2010)]. It has also shown greater disease resistance to gray mold than 'Evie 2' (Rowley et al., 2011). In three separate high 
tunnel studies, 'Albion' was reported to produce $0.29 \mathrm{~kg} /$ plant in South Korea (Ruan et al., 2013), $0.33 \mathrm{~kg} /$ plant in Washington (Hoashi-Erhardt and Walters, 2014), and $1.04 \mathrm{lb} /$ plant in low tunnels in Minnesota (Petran, 2016). In our study, we found 'Albion' to produce a season mean of $0.34 \mathrm{~kg} /$ plant. Similarly to the findings of others, data from this study indicate that 'Albion' has a large fruit average weight during the mid and late-season production periods. 'Albion' and 'Monterey' had the highest values for marketability percent by weight in both years compared with the other cultivars studied. Similarly, Hoashi-Erhardt et al. (2013) found that both 'Albion' and 'Monterey' had a lower proportion of culled fruit and higher marketable yields in high tunnels in Washington. Our results were similar to Ruan et al. (2013), who reported that 'Monterey' produced marketable fruit weight of $0.34 \mathrm{~kg} /$ plant. However, Petran (2016) observed higher total fruit weight for 'Monterey' at $1.10 \mathrm{lb} /$ plant, which was $20 \%$ greater than what we observed in 2014 and even further exacerbated in 2015 .

High tunnel systems are best suited for intensive production of high-value crops for growers to maximize revenue in a limited space (Kadir and Carey, 2004). Strawberry plants could potentially be a good option for high tunnel growers in the central United States. A recent study in Kansas City metropolitan area showed that berries are one of only three fruit crops identified by local growers and buyers as a highdemand crop, and currently, a very small percent of production acreage is being used for berries production (Kansas City Food Hub Working Group, 2015). A recent 2014 survey of fruit and vegetable growers $(n=$ 265 ) showed that $\approx 82 \%$ of the survey participants have adopted high tunnel production or have a plan to do so (C.L. Rivard, unpublished data). The results of this study could help current and future high tunnel growers to diversify their production by planting strawberry during the summer months and this valuable production space during the winter. In addition, high prices are paid for strawberry fruit in October and November, when national production is lowest (Belasco et al., 2013). It has been reported that strawberry plants within Kansas high tunnels experienced an averaged $5^{\circ} \mathrm{C}$ warmer crown temperatures than open-field systems, encouraging early and late-season production (Kadir et al., 2006). Also, high tunnel systems have been successful at limiting damage due to environmental variables such as rain and frost (Jensen and Malter, 1995). In this study, high tunnel production continued until early October, when berries had a smaller average fruit weight and the nighttime temperatures began to drop. Furthermore, the use of the high tunnel system resulted in high marketability percent by weight $(\approx 80 \%)$ that was maintained in both production years, which differed by only 3\% from 2014 to 2015.

Application of EC preharvest reduced strawberry pest presence and enhanced disease control (Dara et al., 2016). It has also been reported that the use of EC positively affects maturity, fruit storage characteristics, and fruit color development for other fruit crops (Koike et al., 2009; Parchomchuk and Meheriuk, 1996; van den Dool, 2006). In our trials, the results of using EC showed no significant differences in total or marketable fruit weight in either year nor did EC affect the incidence of fruit with gray mold. However, differences in total and marketable average fruit weight as well as the marketability were observed during the 2014 trial. Further studies are needed to understand the potential of EC in cooling the internal fruit temperature and affecting fruit production and disease incidence.

\section{Conclusions}

The data presented in this study demonstrate that production of dayneutral strawberry plants in high tunnels in the central United States is feasible with certain cultivars. To our knowledge, this is the first report of this production system and the use of an EC system within a high tunnel during the fruiting period of the dayneutral strawberry. More research is needed to determine the specific economic costs and benefits, but the overall plant productivity we observed was within the range of what is desired by growers to consider them successful (Lantz et al., 2010). Spring-planted day-neutral strawberry could be a new crop for many high tunnel growers in the central United States and beyond that wish to diversify their high tunnel operations or prove a novel high-value crop for their market(s).

Although all cultivars studied fell within the desired total and marketable fruit weight and average weight range in 2014, only Evie 2 and Portola fell within the desired fruit weight in 2015. Furthermore, fruit production by 'Portola' dropped by $15 \%$ from 2014 to 2015 , whereas the mean production of 'Evie 2' was reduced by $30 \%$ and the average drop in production by all the cultivars was $24 \%$. These data suggest that 'Portola' may be a more consistent cultivar for high tunnel production the central United States. 'Portola' also had the largest total and marketable average fruit weight both years and maintained it during the midseason, which may be a desirable characteristic for growers. Clearly, proper cultivar selection is critical for maintaining successful production systems for day-neutral strawberry in the central United States, where the growing climate may not be ideal in all growing seasons. The separation of harvest data into early-, mid-, and late-season time periods allows for further exploration of crop production dynamics and may be valuable to others working with day-neutral strawberry, in high tunnel production systems, or both. Furthermore, these data provide useful information for growers related to strawberry production within a three-season high tunnel. Further controlled studies are needed to identify the effects of plant establishment, EC, and environment on these specific day-neutral cultivars in high tunnels. In addition, an economic analysis will be important to determine the costs and benefits associated with this production system. However, the results of this yield study indicate that growing dayneutral strawberry in high tunnels in the central United States is feasible and highlights the importance of proper cultivar selection.

\section{Literature cited}

Aljibury, F.K., R. Brewer, P. Christensen, and A.N. Kasimatis. 1975. Grape response to cooling with sprinklers. Amer. J. Enol. Viticult. 26(4):214-217.

Belasco, E.J., C. Miles, A.L. Wszelaki, S. Ponnaluru, S. Galinato, and T. March. 
2013. High tunnels are my crop insurance: An assessment of risk management tools for small-scale specialty crop producers. Agr. Resour. Econ. Rev. 42(2):403-418.

Carey, E.E., L. Jett, W.J. Lamont, T.T. Nennich, M.D. Orzolek, and K.A. Williams. 2009. Horticultural crop production in high tunnels in the United States: A snapshot. HortTechnology 19:37-43.

Connor, A.M., J.J. Luby, C.B. Tong, C.E. Finn, and J.F. Hancock. 2002. Genotypic and environmental variation in antioxidant activity, total phenolic content, and anthocyanin content among blueberry cultivars. J. Amer. Soc. Hort. Sci. 127(1):89-97.

Dara, S.K., S. Sandoval-Solis, and D. Peck. 2016. Improving strawberry irrigation with micro-sprinklers and their impact on pest management. Agr. Sci. 7(1):859-868.

Demchak, K. 2009. Small fruit production in high tunnels. HortTechnology 19:44-49.

Demchak, K., J. Harper, L.F. Kime, and W. Lantz. 2010. Strawberry production. Penn State Coop. Ext. UA 290.

Durner, E.F., E.B. Poling, and J.L. Maas. 2002. Recent advances in strawberry plug transplant technology. HortTechnology $12: 545-550$.

Evans, R.J. 2004. Energy balance of apples under evaporative cooling. Trans. Amer. Soc. Agr. Eng. 47(4):1029-1037.

Heidenreich, C., M. Pritts, K. Demchak, E. Hanson, C. Weber, and M.J. Kelly. 2012. High tunnel raspberries and blackberries. Cornell Univ. Dept. Hort. Publ. No. 47.

Hellman, E.W. and J.D. Travis. 1988. Growth inhibition of strawberry at high temperatures. Adv. Strawberry Prod. 7(1):36-39.

Hoashi-Erhardt, W., P. Moore, D. Collins, A. Bary, and C. Cogger. 2013. Evaluation of day-neutral cultivars for organic production in Washington. Acta Hort. 1001:167-174.

Hoashi-Erhardt, W. and T. Walters. 2014. Growing day-neutral strawberries in western Washington. Washington State Univ. Ext. Rpt. FS132E.

Hochmuth, G., D. Cantliffe, C. Chandler, C. Stanley, E. Bish, E. Waldo, D. Legard, and J. Duval. 2006a. Containerized strawberry transplants reduce establishmentperiod water use and enhance early growth and flowering compared with bare-root plants. HortTechnology 16:46-54.

Hochmuth, G., D. Cantliffe, C. Chandler, C. Stanley, E. Bish, E. Waldo, D. Legard, and J. Duval. 2006b. Fruiting responses and economics of containerized and bareroot strawberry transplants established with different irrigation methods. HortTechnology 16:205-210.

Hortynski, J.A., J. Zebrowska, J. Gawronski, and T. Hulewicz. 1991. Factors influencing fruit size in the strawberry (Fragaria ananassa Duch.). Euphytica 56(1):67-74.

Jensen, M.H. and A.J. Malter. 1995. Protected agriculture: A global review, p. 2-3. World Bank Tech. Paper No. 253.

Kader, A.A. 2002. Pre-and postharvest factors affecting fresh produce quality, nutritional value, and implications for human health. Proc. Intl. Congr. Food Production Quality Life, Sassari, Italy, 4-8 Sept. 2000. p. 109-119.

Kadir, S. and E. Carey. 2004. Off-season strawberry production under high tunnel compared to open field in Kansas. HortScience 39:770.

Kadir, S., E. Carey, and S. Ennahli. 2006. Influence of high tunnel and field conditions on strawberry growth and development. HortScience 41:329-335.

Kansas City Food Hub Working Group. 2015. Kansas City Food Hub feasibility study. Greater Kansas City Food Policy Coalition, Kansas City, MO.

Kansas Mesonet. 2014. Historical weather. Olathe, KS. 19 Feb. 2014. <http://mesonet.k-state.edu/weather/ historical/>

Knewtson, S.J., E.E. Carey, and M.B. Kirkham. 2010. Management practices of growers using high tunnels in the central great plains of the United States. HortTechnology 20:639-645.

Koike, S.T., F.G. Zalom, and K.D. Larson. 2009. Bronzing of strawberry fruit as affected by production practices, environmental factors, and thrips. HortScience 44:1588-1593.

Kumakura, H. and Y. Shishido. 1994. The effect of daytime, nighttime, and mean diurnal temperatures on the growth of 'Morioka-16' strawberry fruit and plants. J. Jpn. Soc. Hort. Sci. 62(4):827-832.

Lamont, W.J. 2009. Overview of the use of high tunnels worldwide. HortTechnology 19:25-29.

Lantz, W., H. Swartz, K. Demchak, and S. Frick. 2010. Season-long strawberry production with everbearers for northeastern producers. Univ. Maryland Publ. EB 401.

Ledesma, N., S. Kawabata, and N. Sugiyama. 2004. Effect of high temperature on protein expression in strawberry plants. Biol. Plant. 48(1):73-79.
Ledesma, N. and N. Sugiyama. 2005. Pollen quality and performance in strawberry plants exposed to high-temperature stress. J. Amer. Soc. Hort. Sci. 130(3):341-347.

Masaru, S., M. Uenishi, K. Miyamoto, and T. Suzuki. 2016. Effect of root-zone temperature on the growth and fruit quality of hydroponically grown strawberry plants. Agr. Sci. 8(5):122.

Parchomchuk, P. and M. Meheriuk. 1996. Orchard cooling with pulsed overtree irrigation to prevent solar injury and improve fruit quality of 'Jonagold' apples. HortScience 31:802-804.

Paull, R.E. 1999. Effect of temperature and relative humidity on fresh commodity quality. Postharvest Biol. Technol. 15(3):263-277.

Petran, A. 2016. Performance and impact of strawberry (Fragaria $\times$ ananassa) season extension in the U.S. upper midwest using organic practices. Univ. Minnesota, Minnesota, MA, PhD Diss.

Poling, E.B. 2005. An introductory guide to strawberry plasticulture. 22 Feb. 2018. <https: / / www.agrireseau.net/ petitsfruits/documents/quebec-poling. pdf>.

Poling, E.B. 2006. Plasticulture in the Midwest, p. 100-118. In: M.A. Ellis, R.C. Funt, S. Wright, K. Demchak, E. Wahle, D. Doohan, C. Welty, R.N. Williams, and M. Brown (eds.). Midwest strawberry production guide. Ohio State Univ. Ext. Bul. 926.

Pollack, S. and A. Perez. 2008. Fruit and tree nuts situation and outlook yearbook 2008. U.S. Dept. Agr., Econ. Res. Serv., Washington, DC.

Pritts, M.P. and D. Handley. 1998. Strawberry production guide for the northeast, midwest, and eastern Canada. Cornell Univ. Coop. Ext. NRAE-88.

Roos, D. and D. Jones. 2016. Season extension: Introduction and basic principles. 22 Feb. 2018. <https://growingsmallfarms. ces.ncsu.edu/growingsmallfarms seasonextension $2012 />$.

Rowley, D., B.L. Black, D. Drost, and D. Feuz. 2011. Late-season strawberry production using day-neutral cultivars in high-elevation high tunnels. HortScience 46:1480-1485.

Ruan, J., Y.H. Lee, and Y.R. Yeoung. 2013. Flowering and fruiting of day-neutral and ever-bearing strawberry cultivars in high-elevation for summer and autumn fruit production in Korea. Hort. Environ. Biotechnol. 54(2):109-120.

Salame-Donoso, T.P., B.M. Santos, C.K. Chandler, and S.A. Sargent. 2010. Effect of high tunnels on the growth, yields, and 
soluble solids of strawberry cultivars in Florida. Intl. J. Fruit Sci. 10(3):249-263.

Symons, G.M., Y.J. Chua, J.J. Ross, L.J. Quittenden, N.W. Davies, and J.B. Reid. 2012. Hormonal changes during nonclimacteric ripening in strawberry. J. Expt. Bot. 63(13):4741-4750.

Thompson, A.L., J.R. Gilley, and J.M. Norman. 1993. A sprinkler water droplet evaporation and plant canopy model. I.
Model development. Trans. Amer. Soc. Agr. Eng. 36(3):735-741.

van den Dool, K. 2006. Evaporative cooling of apple and pear orchards. Stellenbosch Univ., Stellenbosch, South Africa, PhD Diss.

Wang, S.Y. and M.J. Camp. 2000. Temperatures after bloom affect plant growth and fruit quality of strawberry. Scientia Hort. 85(3):183-199.
Wells, O. and J.B. Loy. 1993. Rowcovers and high tunnels enhance crop production in the northeastern United States. HortTechnology 3:92-95.

Yang, F. and D.R. Bryla. 2016. Evaporative cooling with sprinklers to reduce heat-related fruit damage in northern highbush blueberry. HortScience 51:S33 (abstr.). 